\title{
Influence of oestradiol and tamoxifen on oestrogen receptors- $\alpha$ and $-\beta$ protein degradation and non-genomic signalling pathways in uterine and breast carcinoma cells
}

\author{
E Horner-Glister ${ }^{1,2}$, M Maleki-Dizaji ${ }^{1}$, C J Guerin ${ }^{3}$, S M Johnson ${ }^{1}$, J Styles ${ }^{1}$ and \\ I N H White' \\ ${ }^{1}$ MRC Molecular Endocrinology Group, Department of Cancer Studies and Molecular Medicine, University of Leicester, Leicester LE2 7 LX, UK \\ ${ }^{2}$ Cancer Biomarkers and Prevention Group, Biocentre, University of Leicester, University Road, Leicester LE1 7RH, UK \\ ${ }^{3}$ MRC Toxicology Unit, Leicester LE1 7RH, UK
}

(Requests for offprints should be addressed to E Horner-Glister; Cancer Biomarkers and Prevention Group, Biocentre, University of Leicester, University Road, Leicester LE1 7RH, UK; Email: elp8@leicester.ac.uk)

\begin{abstract}
Tamoxifen acts as an oestrogen antagonist in the breast reducing cell proliferation, but in the uterus as an oestrogen agonist resulting in increased cell proliferation. Tamoxifen exerts its tissue-specific effects through the oestrogen receptors (ER $\alpha$ or ER $\beta$ ). The levels and functions of the two ERs affect the response of the target tissue to oestrogen and tamoxifen. We examined the control of ER stability in breast and uterine cell lines using western blotting and RT-PCR. In MCF-7 breast-derived cells, ER $\alpha$ and ER $\beta$ proteins were rapidly degraded via the proteasome pathway in response to oestradiol; conversely tamoxifen stabilised both receptors. In Ishikawa uterine-derived cells, oestradiol and tamoxifen stabilised ER $\alpha$ but led to degradation of ER $\beta$ by the proteasome pathway. Further investigations showed that oestradiol induced activation of the non-genomic ERo/Akt signalling pathway in MCF-7 cells. We have demonstrated that the alternative Erk signalling pathway is activated in Ishikawa cells following oestradiol treatment in the absence of an active proteasome pathway and therefore increased levels of ER $\beta$. In conclusion, our data have demonstrated tamoxifen or oestradiol control of ER subtype stability and that non-genomic activation of transcription pathways is cell specific.
\end{abstract}

Journal of Molecular Endocrinology (2005) 35, 421-432

\section{Introduction}

Tamoxifen is widely used for the adjuvant treatment of breast cancer, although epidemiological evidence has shown an increase in endometrial cancers in treated women (Rutqvist et al. 1995, Fotiou et al. 2000, Kloos et al. 2002). In the breast, tamoxifen acts as an oestrogen antagonist, reducing or preventing the proliferation of oestrogen receptor (ER)-positive tumour cells (Guzick et al. 2003, Power \& Thompson 2003). However, in the uterus, tamoxifen acts as an oestrogen agonist resulting in cell proliferation (Goldstein 2001, Pole et al. 2005).

Tamoxifen and other selective ER modulators (SERMs) exert their tissue-specific effects through interaction with one or both of the ERs (ER $\alpha$ or ER $\beta$ ) (McDonnell et al. 2002, Park \& Jordan 2002). In the classical pathway for ER activation, ligand binding causes the receptors to undergo conformational changes and dimerise forming homo- or heterodimers, which bind to the palindromic oestrogen response element (ERE), leading to recruitment of coactivator proteins and transcription of oestrogen responsive genes
(Edwards 2000, Klinge 2001). Recent studies have reported the importance of cell membrane-associated ER (Kelly \& Levin 2001) in the activation of cytoplasmic signalling cascades, although there are considerably fewer membrane than nuclear receptors (Razandi et al. 1999). Rapid non-genomic signalling through pathways involving phosphotidylinositol-3 kinase (PI3K)/Akt or Erk1/Erk2, leading to the transcription of target genes, has been described (Pedram et al. 2002, Song et al. 2002), suggesting that some of the proliferative effects of oestradiol may be mediated through these mitogenic pathways. This non-genomic effect of oestrogens has added to the broad range of transcriptional responses that can be produced by ligand-bound ER in different cell types.

Control of ER $\alpha$ protein levels has been studied within various cell types and it is now generally accepted that this protein is targeted for rapid degradation via the ubiquitin-proteasome pathway in response to oestradiol in breast cancer cells (Dowsett \& Ashworth 2003). The control and degradation pathways for $\operatorname{ER} \beta$ remain unclear and as yet there is not a universally accepted 
mechanism for the control of levels of either ER $\alpha$ or $\mathrm{ER} \beta$ in uterine cells. ER $\alpha$ and $\mathrm{ER} \beta$ proteins may be degraded differentially in breast and uterine cells in response to oestradiol and tamoxifen, thus providing some mechanistic evidence for the diverse response of these tissues. There is evidence to suggest that the activity of the proteasome pathway controlling ER $\alpha$ degradation in MCF-7 cells is directly linked to activation of transcription through the ERE (Reid et al. 2003).

If the magnitude of transcriptional activity within cells is directly related to the cellular concentration of the ER, regulatory mechanisms controlling ER protein levels could alter its transcriptional output. In this paper we explore the activation of alternative mitogenic nongenomic signalling pathways. Further aims of this study were to establish previously undefined mechanisms for ER $\beta$ degradation in the MCF-7 cell type. Comparisons were made with $\mathrm{ER} \alpha$ and $\mathrm{ER} \beta$ protein degradation in the uterine adenocarcinoma-derived Ishikawa cell line. The differential effect of oestradiol or tamoxifen on ER protein levels and subsequent activation of the non-genomic signalling pathways was investigated.

\section{Materials and methods}

\section{Human cell culture}

Human breast adenocarcinoma-derived MCF-7 cells (ECACG, Salisbury, Wiltshire, UK; were maintained in Dulbecco's modified Eagles' media (DMEM)/F12 (Invitrogen) supplemented with $2 \mathrm{mM}$ glutamax (Invitrogen) and 10\% foetal calf serum (FCS; Invitrogen). Human uterine epithelial carcinoma-derived Ishikawa cells (ECACG) were maintained in RPMI-1640 media (Invitrogen) supplemented as described above. For visualisation of ER $\beta$ by western blotting, Ishikawa cells were transfected with an ER $\beta$ expression construct as described previously (Jones et al.1999) prior to treatment. All media were phenol red free and cell cultures were maintained in media containing $10 \%$ dextran-coated charcoal-stripped (DCST) FCS for $72 \mathrm{~h}$ before dosing, to ensure depletion of hormones and growth factors in the calf serum.

\section{Western blotting and protein analysis}

Cells were dosed with culture media containing the peptide aldehyde proteasome inhibitor MG115 $\left(10^{-6} \mathrm{M}\right)$ (Sigma) and incubated for $1 \mathrm{~h}$ at $37^{\circ} \mathrm{C}$, $17 \beta$-oestradiol $\left(\mathrm{E}_{2} ;\right.$ Sigma) or 4-hydroxytamoxifen (TAM; Sigma) were added at $10^{-8} \mathrm{M}$ and $10^{-6} \mathrm{M}$ respectively for $3 \mathrm{~h}$ at $37^{\circ} \mathrm{C}$. For selective inhibition of $\mathrm{PI} 3 \mathrm{~K} / \mathrm{Akt}$ and MEK/Erk1/2 signalling pathways the

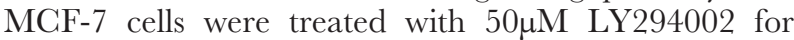
60 min prior to dosing with $\mathrm{E}_{2}$ (inhibition of PI3K phosphorylation of Akt) and the Ishikawa cells were treated with $30 \mu \mathrm{M}$ PD98059 (Santa Cruz Biotechnologies, Santa Cruz, CA, USA) in combination with $\mathrm{E}_{2}$ for inhibition of MEK phosphorylation of Erk1/2. Cells were washed with phosphate-buffered saline (PBS) and lysed in ice-cold protein extraction buffer (Song et al. 2002). For preliminary analysis of ER cellular localisation, nuclear and cytosolic fractions were produced using cells grown in culture media supplemented as above for $72 \mathrm{~h}$ and prepared with the NE-PER nuclear and cytoplasmic extraction reagents kit (Pierce, Perbio Science, Northumberland, UK) according to the manufacturer's instructions. Protein concentration was determined using the BCA protein assay kit (Sigma) and measured using a BMG fluorostar plate reader (BMG Lab Technologies, Offenburg, Germany) at $540 \mathrm{~nm}$. Proteins were analysed by PAGE $(7 \cdot 5 \%$ gels $)$ and transferred onto nitrocellulose membrane (Amersham Pharmacia Biotech, Amersham, Bucks, UK). Positive controls for antibody specificity were $10 \mathrm{ng}$ recombinant protein (rhER $\alpha$ and rhER $\beta$; Calbiochem, Nottingham, UK). Membranes were blocked in $5 \%(\mathrm{w} / \mathrm{v})$ non-fat milk in $0 \cdot 1 \%$ PBS Tween-20 for 12-18 h. ER $\alpha$ protein was detected with $\mathrm{H}-184$ rabbit polyclonal antibody (Santa Cruz Biotechnologies) and ER $\beta$ with 06-629 rabbit polyclonal antibody (Upstate Biotechnologies, Dundee, UK) or GR-39 mouse monoclonal (Oncogene). Akt protein was detected with SC-5289 mouse monoclonal (Santa Cruz Biotechnologies) and phosphorylated Akt (pAKT) with 92715 rabbit polyclonal (Gell Signaling, Hertfordshire, UK). Western blots were re-probed with antibody to glyceraldehyde-3-phosphate dehydrogenase (GAPDH) protein (Biogenesis Ltd, Poole, UK). HRP-conjugated anti-rabbit and anti-mouse secondary antibodies (Santa Cruz Biotechnologies) and the Pierce super signal chemiluminescence detection system were used to visualise immunoreactivity. Data were collected using a Syngene (Cambridge, Cambs, UK) GeneGnome gel documentation system and protein expression was normalised to GAPDH levels. Statistical analysis of variance (ANOVA) or two sample $t$-tests were performed where appropriate $(P \leq 0 \cdot 05)$.

\section{Fluorescence-based determination of proteasome activity using Suc-LLVY-AMC}

Proteasome activity was assessed by a peptide substrate succinyl-LLVY-7-amino-4-methylcoumarin (Suc-LLVYAMC) for the proteasome complex. Protein extract $(100 \mu \mathrm{M})$ was incubated with $50 \mu \mathrm{M}$ Suc-LLVY-AMC (Bachem Biochemica, St. Helens, UK) in a total volume of $200 \mu \mathrm{l}$ with $5 \mathrm{mM} \mathrm{MgCl}, 5 \mathrm{mM}$ ATP, $50 \mathrm{mM}$ Tris- $\mathrm{HCl}, \mathrm{pH} 7 \cdot 8,20 \mathrm{mM} \mathrm{KCl}$ and $5 \mathrm{mM}$ magnesium acetate for $1 \mathrm{~h}$ at $37^{\circ} \mathrm{C}$, terminated by $200 \mu \mathrm{l} 0 \cdot 1 \mathrm{M}$ sodium borate. The fluorescence of aminomethylcoumarin was measured in a fluorometer. Standard 
curves were prepared containing 7-amino-4methylcoumarin using the same reagent buffers.

\section{Confocal microscopy}

MCF-7 or Ishikawa cells were grown for $72 \mathrm{~h}$ in four-well glass chamber slides in culture medium supplemented with charcoal-stripped serum as detailed above. Cells were pretreated with MG115 $\left(10^{-6} \mathrm{M}\right)$ for $1 \mathrm{~h}$ before dosing with $\mathrm{E}_{2}\left(10^{-8} \mathrm{M}\right)$, TAM $\left(10^{-6} \mathrm{M}\right)$ or ethanol vehicle (control) for $3 \mathrm{~h}$. Cells were fixed for $30 \mathrm{~min}$ in methanol at $-20{ }^{\circ} \mathrm{C}$, washed in PBS and permeabilised with $0 \cdot 4 \%$ Triton X-100 10 min before blocking with $2 \%$ normal goat serum $/ 4 \%$ BSA for $30 \mathrm{~min}$ at $37^{\circ} \mathrm{C}$. Primary mouse monoclonal antibodies were incubated at $4{ }^{\circ} \mathrm{C}$ overnight. ER $\alpha$ was detected with Santa Cruz Biotechnologies D12 at 1:20 dilution in blocking buffer and ER $\beta$ with Serotec (Oxford, UK) MCA1973S at 1:20 dilution also in blocking buffer. Secondary antibody was AlexaFluor 488 (Molecular Probes, Eugene, OR, USA) at 1:500 in blocking buffer, incubated at $4{ }^{\circ} \mathrm{C}$ overnight in darkness. Hoechst 33342 dye was subsequently added for nuclear staining. Confocal microscopic images were captured using a Zeiss LSM 510 META multi-photon confocal microscope (Carl Zeiss (UK) Ltd, Welwyn Garden City, Herts, UK). Low magnification Z-series were collected with a $20 \times$ Plan-neofluar lens and high resolution series using a $40 \times 1.3$ oil immersion Plan-apocromat lens or a $63 \times$ $\mathrm{C}$-apochromat 1.2 na water immersion lens. Threedimensional reconstructions of each data set were performed to examine each confocal Z-series using Zeiss Advanced Imaging Microscopy (Carl Zeiss Ltd). Nuclear staining was performed using Hoechst $33258(10 \mu \mathrm{g} / \mathrm{ml}$; Molecular Probes) in PBS for $10 \mathrm{~min}$ and excited in multi photon mode with a Tsuanmi Infra red laser (Spectra Physics, Mountain View, CA, USA) at $760 \mathrm{~nm}$ and detected with a 365-405 nm band pass filter. AlexaFluor 488-labelled secondary antibody (Molecular Probes) was excited with a $488 \mathrm{~nm}$ Argon laser line (LASOS Lastertechnik GMBH, Germany) and detected using a long pass $505 \mathrm{~nm}$ filter.

\section{mRNA extraction and RT-PCR}

MCF-7 and Ishikawa cells were counted before lysis and mRNA extraction by oligo dT-linked Dynabeads (Dynal, Biotech Ltd, Wirral, UK) according to the manufacturer's instruction. Dynabead-linked mRNA was used as a template for reverse transcription at $42{ }^{\circ} \mathrm{C}$ for $1 \mathrm{~h}$ (Promega reagents). Hot-start PCR performed with GAPDH was a control (Hall et al. 1998). PCR primer sequences for $\mathrm{ER} \alpha$ and $\mathrm{ER} \beta$ have been described previously (Tschugguel et al. 2003). Data were collected using a Syngene GeneGnome gel documentation system and expression was normalised to GAPDH levels. (a)

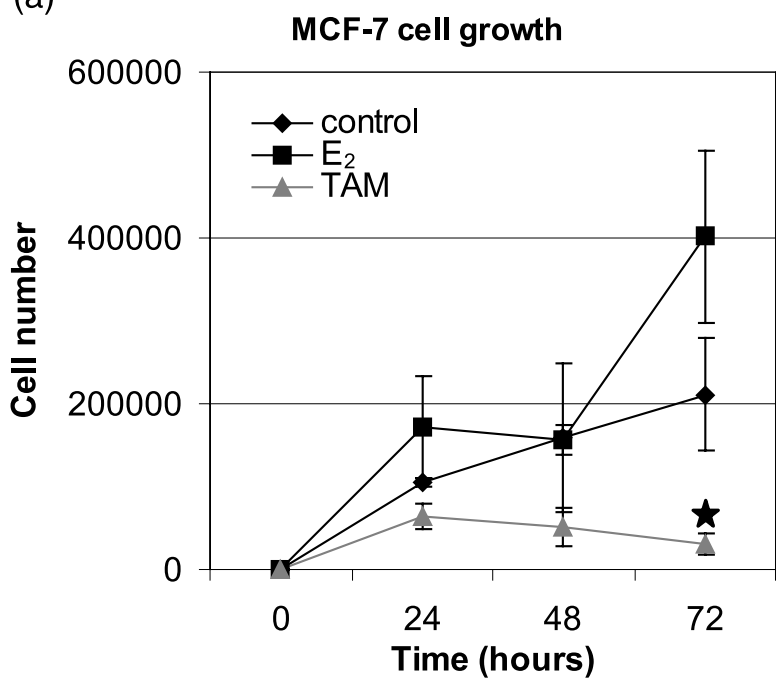

(b)

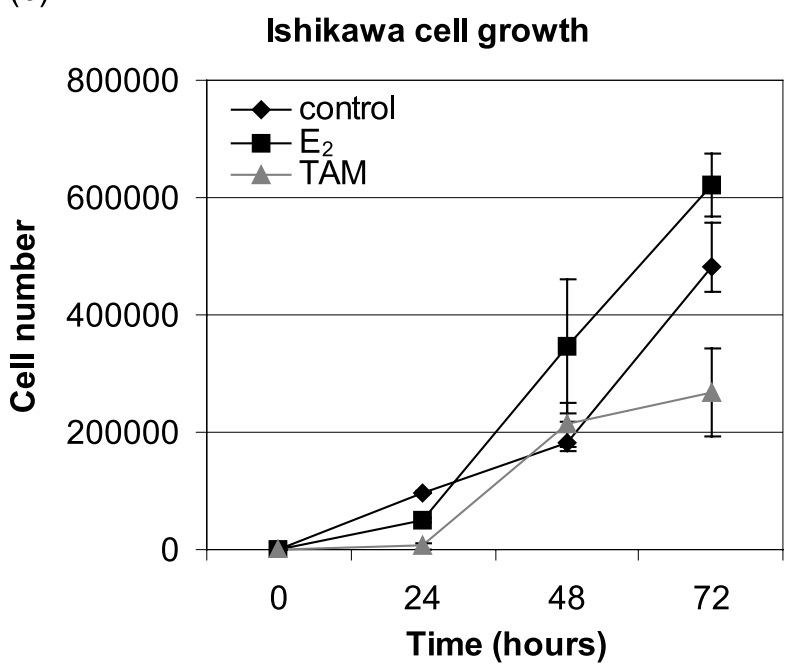

Figure 1 Representative growth curves for (a) MCF-7 and (b) Ishikawa cells and the effects of oestradiol or tamoxifen. Cells maintained in phenol red-free DMEM/F12 or RPMI containing $10 \%$ DCST-FCS for $72 \mathrm{~h}$ before dosing with $10^{-8} \mathrm{M} \mathrm{E}_{2}, 10^{-6} \mathrm{M}$ TAM or vehicle (ethanol control). Cells were counted at 24,48 and $72 \mathrm{~h}$ after dosing using a haemocytometer. Data are corrected for variation in cell number at time 0 and formulated from mean values \pm S.E. of three experiments. ${ }^{*} P \leq 0.05$ (ANOVA).

\section{Results}

\section{Oestradiol-induced degradation of ER $\alpha$ is cell type specific}

The effect of tamoxifen on proliferation of the breast and uterine cell types was investigated. $\mathrm{E}_{2}$ stimulated cell proliferation in both cell types (Fig. 1). TAM $\left(10^{-6} \mathrm{M}\right)$ significantly $(P \leq 0 \cdot 05)$ inhibited cell proliferation in the 


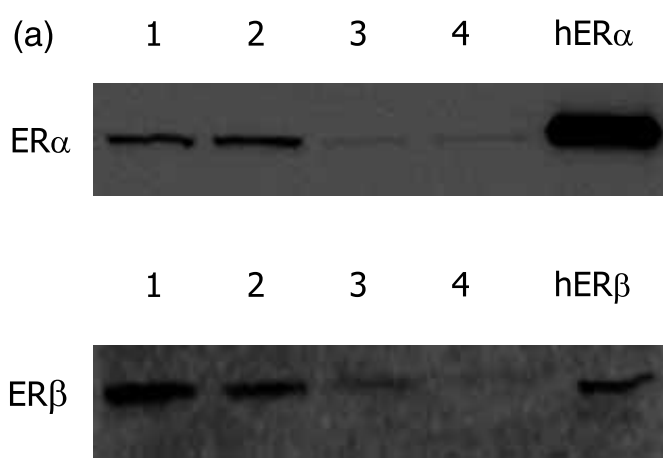

(b) ER alpha protein expression in MCF-7 cells

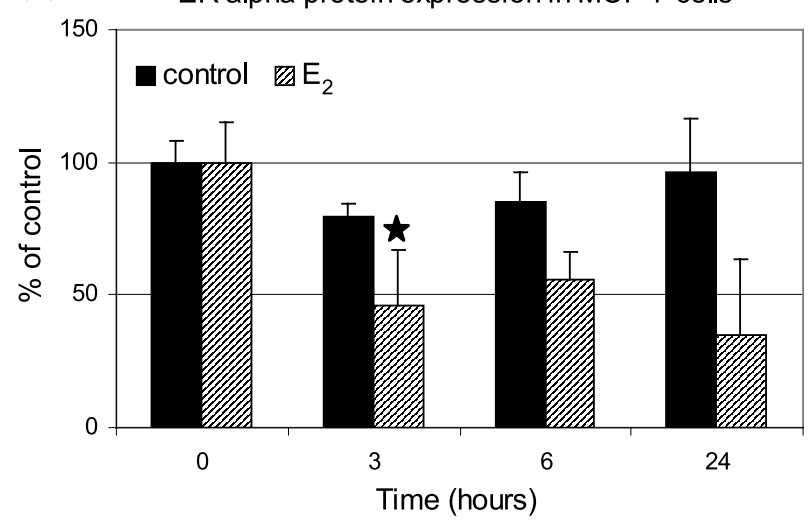

Figure 2 Detection of ER proteins within whole cell lysates. (a) Whole cell lysates $(50 \mu \mathrm{g})$ of MCF-7 (lanes 1-2), Ishikawa (lanes 3-4) and $10 \mathrm{ng}$ of appropriate recombinant protein separated using PAGE western blots, probed with Santa Cruz 184 (human ER $\alpha$ ) or Oncogene GR-39 (human ER $\beta$ ) primary antibodies. (b) ER $\alpha$ protein expression from Western blots of $50 \mu \mathrm{g}$ MCF-7 whole cell lysates maintained in phenol red-free DMEM/F12 containing 10\% DCST-FCS for $72 \mathrm{~h}$ before dosing with $10^{-8} \mathrm{M} \mathrm{E}_{2}$. Cells were lysed at $0,3,6$ and $24 \mathrm{~h}$. Expression levels are expressed as percentage of ER $\alpha$ protein at time 0 . Results represent the mean \pm S.E. of three experiments. ${ }^{*} P \leq 0.05$ (ANOVA).

MCF-7 cell line (Fig. 1a). This anti-proliferative effect was not observed to the same degree in the Ishikawa cell line, indicating a partial oestrogen agonist effect in these cells (Fig. 1b). Antibody specificity is shown in Fig. 2a, where recombinant human $\mathrm{ER} \alpha$ and $\mathrm{ER} \beta$ proteins were detected, no other non-specific binding of the antibodies was observed and only a band of the correct molecular weight for the wild-type protein forms was visualised from the cell lysates. A representative time-point at which to study the effect of $\mathrm{E}_{2}$ treatment on $\mathrm{ER} \alpha$ protein was determined in MCF-7 cells. ER $\alpha$ protein diminished over a 24-h period in MCF-7 cells in a time-dependent manner. The earliest significant decrease was observed at $3 \mathrm{~h}$ where treatment with $\mathrm{E}_{2}$ resulted in an $\sim 50 \%$ $(P \leq 0 \cdot 05)$ loss of ERa (Fig. 2b).
The peptide aldehyde proteasome inhibitor MG115 has previously been demonstrated to have a role in apoptosis (Lopes et al. 1997). The toxicity of MG115 was therefore assessed by a trypan blue exclusion assay in MCF-7 and Ishikawa cells. The viability of both cell types remained unaffected after 1-h pretreatment with MG115, and lysis after 3-h incubation with $\mathrm{E}_{2}$ or TAM (Fig. 3a and b). To assess the efficacy of proteasome pathway inhibitors, the effects of MG115, MG132 or lactacystin on proteasome activity in MCF-7 cells were determined by a fluorescence assay based on the hydrolysis of a peptide substrate (Suc-LLVY-AMG) for the proteasome complex (Nandi et al. 1997, Kisselev et al. 1999). Results showed that MG115 is as efficient as others, alone or in combination (Fig. 3c). To address the observation that the peptide was still subject to degradation even in the presence of the proteasome inhibitors, the cells were treated with a cocktail of protease inhibitors, in combination with the MG115 proteasome inhibitor. In this additional experiment, full inhibition was achieved suggesting that this peptide is also a target for the protease pathway.

The effect of $\mathrm{E}_{2}$ or TAM on ER $\alpha$ protein levels was assessed in MCF-7 and Ishikawa cells. ER $\alpha$ protein levels were reduced in MCF-7 cells dosed for $3 \mathrm{~h}$ with $\mathrm{E}_{2}$ (Fig. 4a). Pretreatment with the proteasome inhibitor MG115 for $1 \mathrm{~h}$ before dosing with $\mathrm{E}_{2}$ abolished this effect and led to an increase of protein above control level. It is interesting to note that MG115 treatment alone led to significant stabilisation of the $\mathrm{ER} \alpha$ protein $(P \leq 0.05$; Fig. 4a). As ER $\alpha$ contains a PEST (rich in proline, glutamate and aspartate, serine and threonine) sequence (Pakdel et al. 1993) which is recognised by proteases including calpains, we pretreated the cells with 2S,3S-trans-epoxysuccinyl-L-leucylamido-3-methylbutane ethyl ester E-64-d (calpain inhibitor) in place of MG1 15. In this experiment, $\mathrm{E}_{2}$-induced degradation of $\mathrm{ER} \alpha$ was still observed, eliminating the calpain protease as a possible degradation pathway (data not shown). Ishikawa cell lysates did not show any reduction in ER $\alpha$ levels following $\mathrm{E}_{2}$ treatment compared with control (Fig. 4b) and treatment of the cells with MG115 alone did not lead to a significant increase in $\mathrm{ER} \alpha$ protein levels. Western blot analysis of MCF-7 and Ishikawa cell lysates dosed for $3 \mathrm{~h}$ with TAM did not show a decrease of ER $\alpha$ protein in either case (Fig. 4a and b).

\section{Tamoxifen-induced degradation of ER $\beta$ is also cell type specific}

MCF-7 cells, after $3 \mathrm{~h}$ exposure to $\mathrm{E}_{2}$, showed significant rapid degradation of ER $\beta$ protein $(P \leq 0 \cdot 05$; Fig. 4c). When cells were pretreated with MG115, levels of ER $\beta$ remained similar to those of control cells. In the Ishikawa cells, reduction in ER $\beta$ protein was also observed in response to $\mathrm{E}_{2}$ treatment; pretreatment of 
(a)

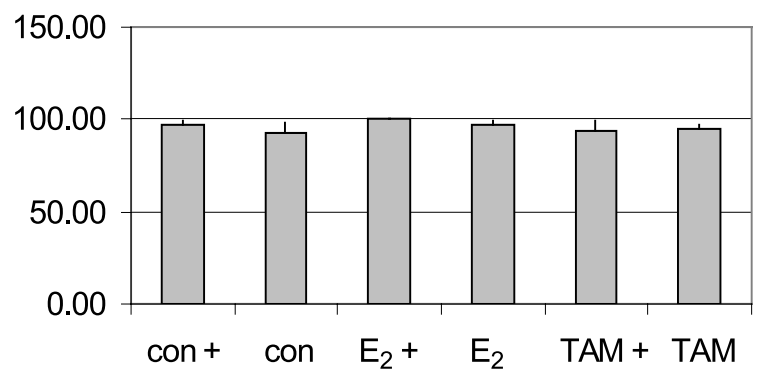

Treatment (+/- 10uM MG115)

(b)

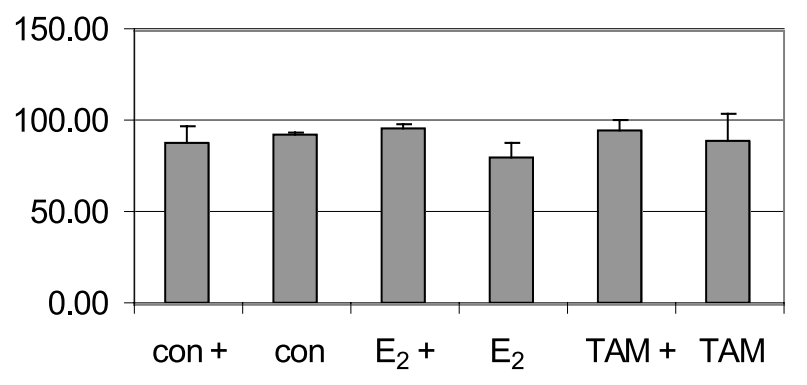

Treatment (+/- 10uM MG115)

(c)

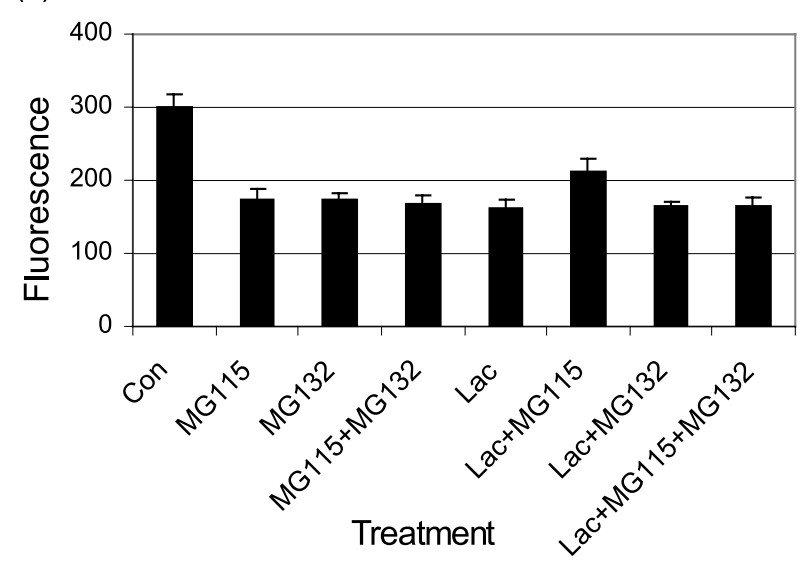

Figure 3 Effect of proteasome inhibitor (MG115; $10^{-6} \mathrm{M}$ ) $1 \mathrm{~h}$ pretreatment on cell viability $3 \mathrm{~h}$ following dosing with $10^{-8} \mathrm{M}$ $E_{2}$ or $10^{-6}$ M TAM. (a) MCF-7 cell viability, (b) Ishikawa cell viability and (c) representative graph of proteasome activity in MCF-7 cells dosed with various proteasome pathway inhibitors (10-6 M MG 115, MG132 or lactacystin; Sigma) and lysed after $4 \mathrm{~h}$. Fluorescence levels produced by the hydrolysis of Suc-LLVY-AMC were assayed. Values are expressed as percentage viability ( $a$ and $b)$ formulated from mean values \pm S.E. of three experiments. Con, control; lac, lactacystin.

these cells with the MG115 proteasome inhibitor resulted in a large increase in ER $\beta$ protein levels (Fig. 4d). The effect of TAM as ligand for ER $\beta$ was assessed in both cell lines. In MCF-7 cells, treatment with TAM led to an increase of ER $\beta$ protein suggesting that, as with $\mathrm{ER} \alpha$, this compound may stabilise the receptor (Fig. 4c). Western blot analysis of TAM-treated Ishikawa cells showed a loss of ER $\beta$ protein; pretreatment with the proteasome inhibitor resulted in an increase of ER $\beta$ protein above control level (Fig. 4d).

\section{Confocal microscopy}

Immunocytochemical detection of $\mathrm{ER} \alpha$ and $\operatorname{ER} \beta$ by confocal microscopy in the MCF-7 cells demonstrated that $\mathrm{ER} \alpha$ was detectable primarily in the nucleus, as indicated by Hoechst staining; there was also cytoplasmic localisation of the protein. ER $\beta$ was also located predominantly in the nucleus (Fig. 5a, b and inset). However, in the Ishikawa cells, ER $\alpha$ was detected principally in the cytoplasm while ER $\beta$ was located mainly in the nucleus (Fig. 5c and d). Treatment of MCF-7 cells with MG115 alone (Fig. 5f) resulted in a greater nuclear ER $\alpha$ immunoreactivity relative to vehicle-treated controls (Fig. 5e). Treatment with $\mathrm{E}_{2}$ (Fig. $5 \mathrm{~g}$ ) resulted in loss of $\mathrm{ER} \alpha$ signal relative to controls and this was prevented by pretreatment with MG115 (Fig. 5 h). TAM treatment increased the levels of nuclear staining for ER $\alpha$ (Fig. 5i) but this immunoreactivity was not further enhanced by pretreatment with MG115 (Fig. 5j). In MCF-7 cells, ER $\beta$ was much less responsive to pretreatment with MG115 (Fig. 5 l) relative to controls (Fig. 5k). In contrast, we were unable to detect changes in staining intensities of $\mathrm{ER} \alpha$ (or $\mathrm{ER} \beta$ ) protein in the Ishikawa cells by the immunostaining methods employed following MG115, $\mathrm{E}_{2}$ or TAM treatments (data not shown).

\section{RT-PCR analysis of ER $\alpha$ and ER $\beta$ mRNA levels following $E_{2}$ and TAM treatment}

We wanted to exclude the possibility that the effects we observed on ER protein levels were due to regulation of mRNA. ER $\alpha$ mRNA levels were not significantly altered in either cell line after a 3 -h incubation with either $\mathrm{E}_{2}$ or TAM relative to the GAPDH housekeeping gene (Fig. 6a and b). However, a significant increase in ER $\beta$ mRNA compared with control $(P \leq 0.05)$ was observed following $3 \mathrm{~h}$ of treatment with $\mathrm{E}_{2}$ in the MCF-7 cell line, conversely TAM led to a decrease in ER $\beta$ mRNA (Fig. 6c and d). Pretreatment of the cells with MG115 did not influence changes in the mRNA levels with either compound and consequently the mechanisms responsible were not investigated further.

\section{$E_{2}$ activates non-genomic signalling via Akt in MCF-7 cells}

We investigated the potential of $\mathrm{E}_{2}$ and TAM to activate ER-initiated non-genomic signalling pathways, and any 
(a)

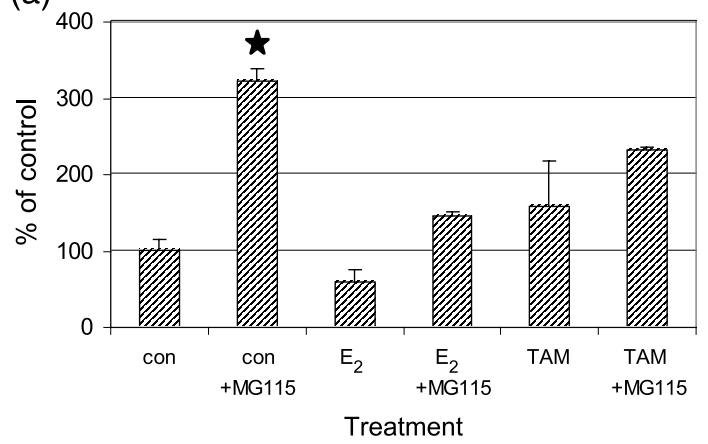

(b)

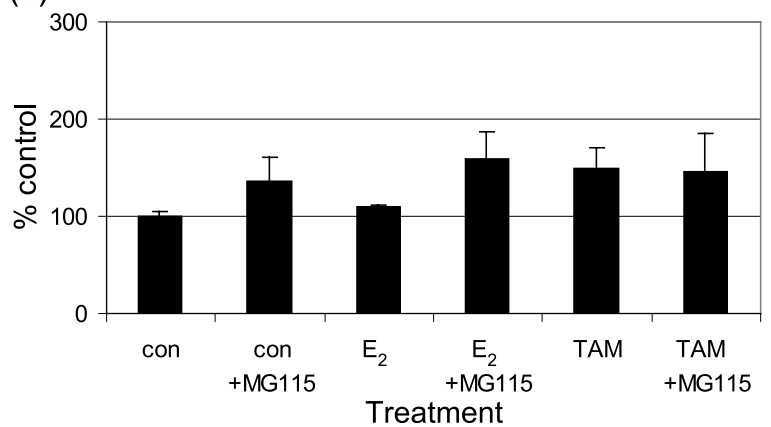

(c)

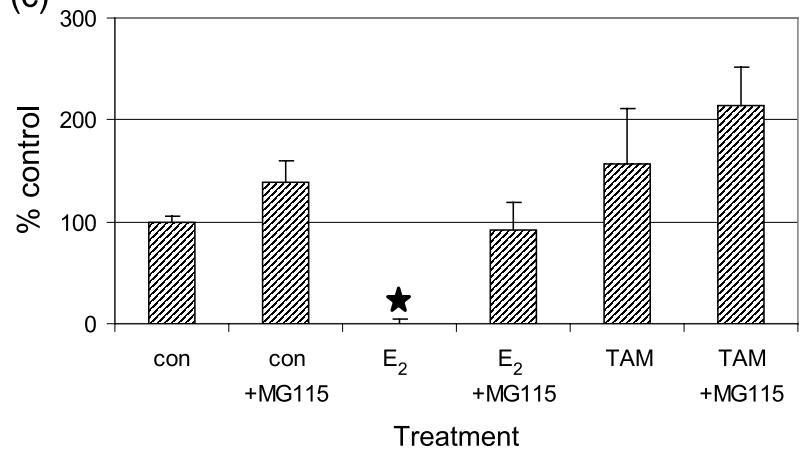

(d)

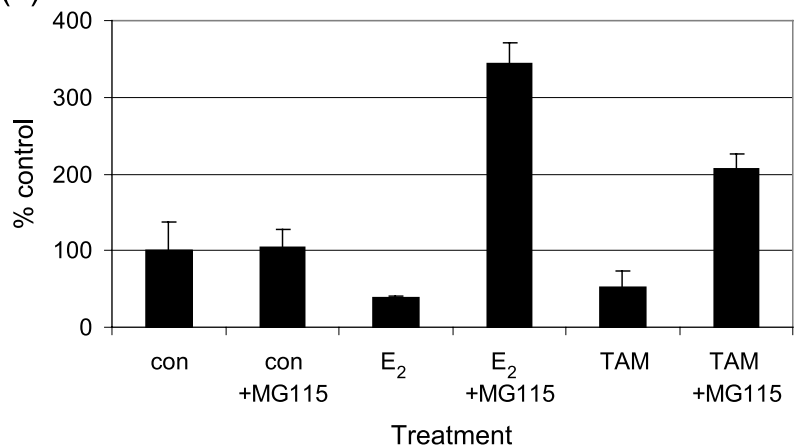

Figure 4 Western blot analysis of (a) ER $\alpha$ protein expression in MCF-7 and (b) Ishikawa cells. ER $\beta$ expression in MCF-7 (c) and Ishikawa (d) cells. Cells were pretreated for $1 \mathrm{~h}$ with $10^{-6} \mathrm{M} \mathrm{MG115}$ and then dosed for $3 \mathrm{~h}$ with $10^{-8} \mathrm{M} \mathrm{E}_{2}$ or $10^{-6} \mathrm{M}$ TAM. Whole cell lysates were prepared after a total of $4 \mathrm{~h}$. ER expression is expressed as percentage of control formulated from mean values normalised to GAPDH expression \pm S.E. ${ }^{*} P \leq 0.05$ (ANOVA). Con, control.

subsequent links to altered ratios of $\operatorname{ER} \alpha: \operatorname{ER} \beta$ proteins levels by inactivating the proteasome pathway. MCF-7 lysates showed a significant increase in Akt phosphorylation by $30 \mathrm{~min}$ following dosing of the cells with $\mathrm{E}_{2}$ $(P \leq 0 \cdot 05$; Fig. 7a). This significant increase in Akt phosphorylation was blocked by pretreatment of the cells

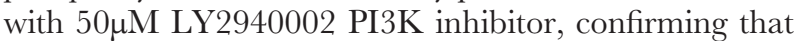
Akt was phosphorylated by PI3K in response to $E_{2}$. Pretreatment of the cells with the proteasome pathway inhibitor MG115 did not affect activation of the Akt pathway. In the Ishikawa cells, Akt phosphorylation was not significantly increased (Fig. 7b). Western blot analysis of $\mathrm{ER} \alpha$ protein levels within nuclear and cytosolic/cell membrane fractions from MCF-7 cells showed that they have detectable levels of the protein in both fractions.

Several conflicting reports have been published as to whether proliferation of MCF-7 cells stimulated by $\mathrm{E}_{2}$ is coupled to phosphorylation of Erk1/2 and activation of the MAP kinase (MAPK) non-genomic signalling pathway. We assessed Erk1/2 phosphorylation levels in both cell types. No increase in phosphorylation of Erk1/2 was observed in MCF-7 cells following $\mathrm{E}_{2}$ or TAM treatment (Fig. 8a). However, rapid activation of the pathway was observed when MCF-7 cells were treated with epidermal growth factor (EGF), a well-documented activator of MAPK (data not shown). Interestingly, phosphorylation of Erk1/2 is significantly induced in the Ishikawa cell type, $30 \mathrm{~min}$ after treatment with $\mathrm{E}_{2}$, but only in cells with an MG115-inhibited proteasome pathway $(P \leq 0 \cdot 05$; Fig. $8 \mathrm{~b})$. When cells were incubated with $30 \mu \mathrm{M}$ PD98059, MEK inhibitor phosphorylation of Erk1/2 was abolished confirming that MEK was responsible for the phosphorylation of Erk1/2 in response to $\mathrm{E}_{2}$ treatment.

\section{Discussion}

The aim of this study was to investigate the role of ligand-mediated degradation and transcription activation pathways in ER subtype-mediated action of tamoxifen and oestradiol, comparatively between breast and uterine cancer cells. We have shown that the ER $\beta$ protein is targeted for degradation following oestradiol binding in the MCF-7 breast carcinoma cell type and that inhibition of the proteasome pathway stops this loss of protein (Fig. 4c). Our results have suggested that this is independent of ER gene transcription as the loss of protein was not accompanied by a decrease in mRNA 

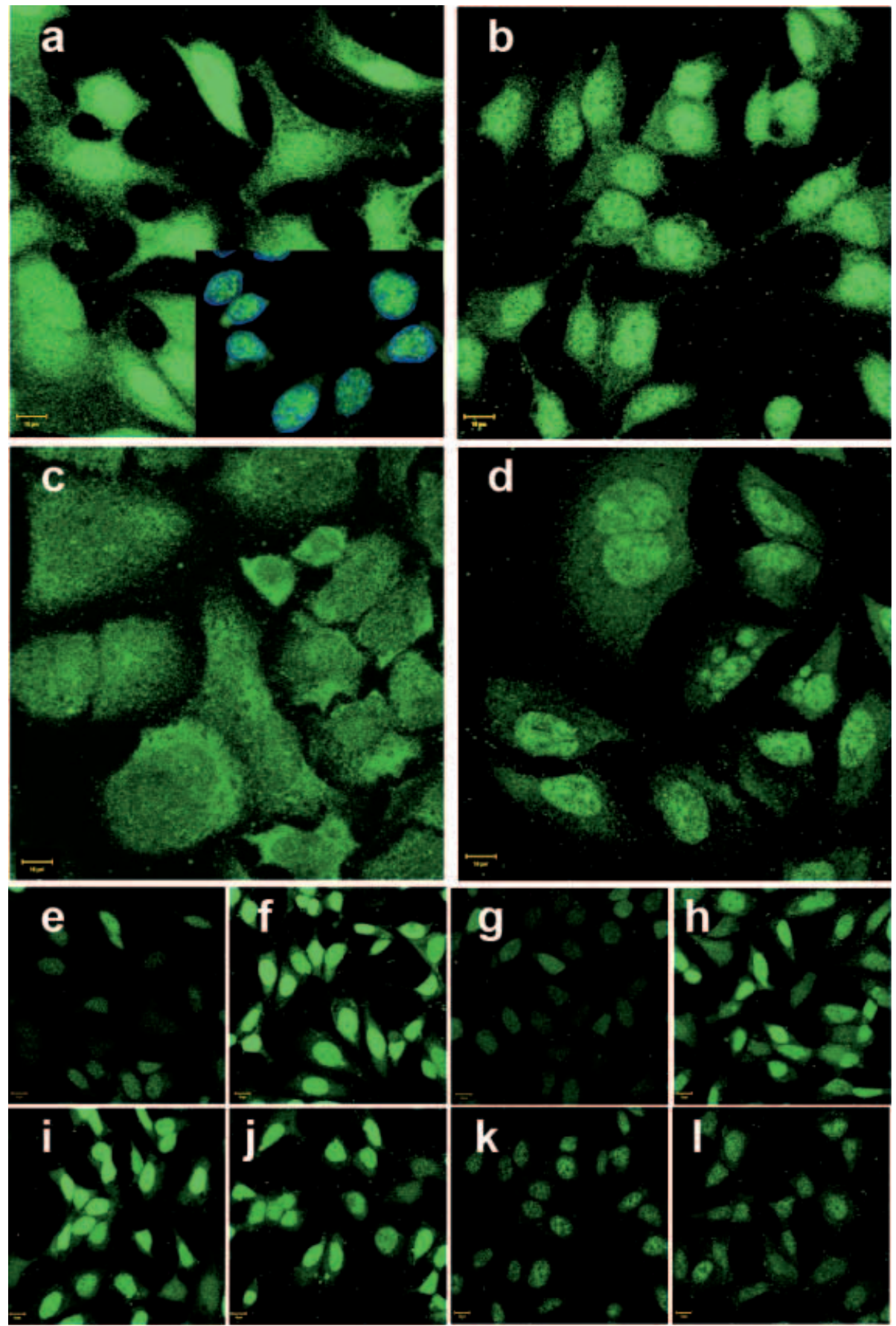

Figure 5 Confocal immunohistochemical localisation of ER $\alpha$ and ER $\beta$ in MCF-7 and Ishikawa cells showing the effects of $1 \mathrm{~h}$ pretreatment with $10^{-6} \mathrm{M} \mathrm{MG} 115$ followed by $3 \mathrm{~h} 10^{-8} \mathrm{M} \mathrm{E}_{2}$ or $10^{-6} \mathrm{M}$ TAM. Cells were grown for $72 \mathrm{~h}$ in chamber slides at $37^{\circ} \mathrm{C}$ in $5 \% \mathrm{CO}_{2}$ in air in charcoal-stripped medium before dosing and fixing in methanol at $-20{ }^{\circ} \mathrm{C}$ as described in Materials and methods. ER $\alpha$ and ER $\beta$ were detected with mouse monoclonal primary antibodies and anti-mouse Alexa 488-conjugated secondary antibody. Hoechst 33342 dye was subsequently added for nuclear staining. Pictures were taken using standardised photomultiplier gain settings. The bars represent $10 \mu \mathrm{m}$. (a and b) MCF-7 cells and (c and d) Ishikawa cells. (a and c) ER $\alpha$ and (b and d) ER 3 . Inset in (a) shows ER $\alpha$ (green) predominantly co-localising with Hoechst nuclear staining (blue). (e-j) ER $\alpha$ in MCF-7 cells showing the effect of pretreatments: (e) vehicle control, (f) MG115 alone, (g) $E_{2}$, (h) MG115 pretreatment followed by $E_{2}$, (i) TAM and (j) MG115 pretreatment followed by TAM. ( $k$ and I) ER $\beta$ in MCF-7 cells: (k) vehicle control and (I) pretreated with MG115 alone. These images are representative of three separate experiments. 
(a)

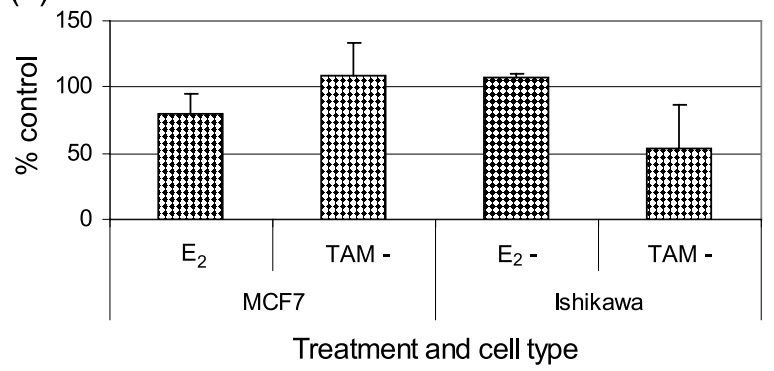

(b)

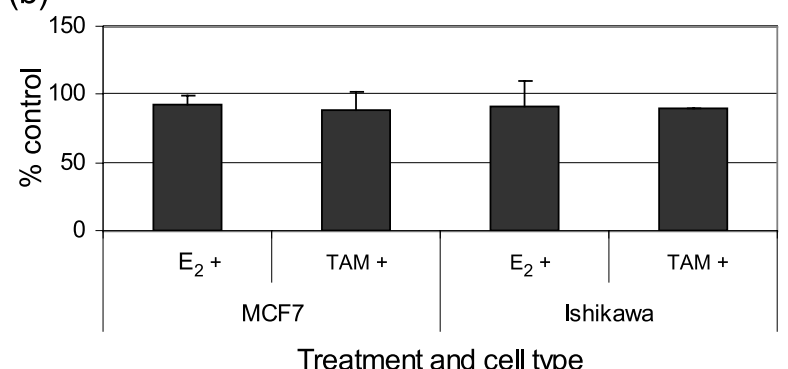

(c)
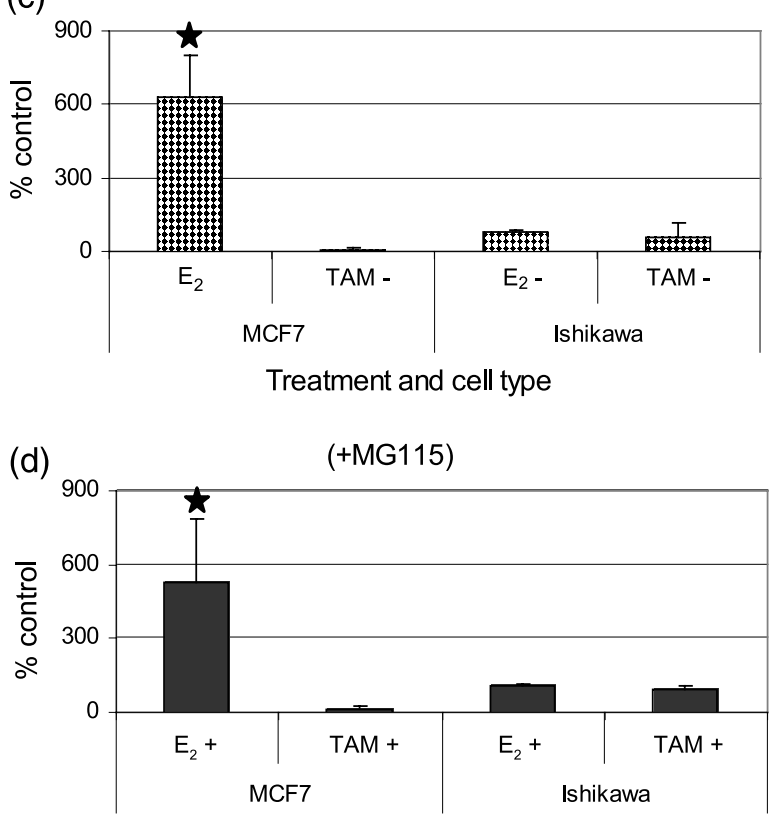

Treatment and cell type

Figure 6 RT-PCR analysis of (a and b) ER $\alpha$ and (c and d) ER $\beta$ mRNA expression. Cells were pretreated for $1 \mathrm{~h}$ with $10^{-6} \mathrm{M}$ MG115 and dosed for $3 \mathrm{~h}$ with $10^{-8} \mathrm{M} \mathrm{E}_{2}$ or $10^{-6} \mathrm{M}$ TAM and mRNA was extracted by oligo dT-linked Dynabeads after a total of $4 \mathrm{~h}$. ER mRNA expression is expressed as percentage of control formulated from mean values $\pm S$.E. ${ }^{\star} P \leq 0.05$ (ANOVA).

and, in fact, a significant increase of ER $\beta$ mRNA was observed in line with previous findings (Cappelletti et al. 2003) (Fig. 6c). Oestradiol-induced proteasome- mediated ER $\beta$ degradation has been described in human vascular endothelial cells (Tschugguel et al. 2003) and in human aortic smooth muscle cells (Barchiesi et al. 2004). A further study where MCF-7 cells were transiently transfected with an ER $\beta$ expression plasmid showed that the proteasome inhibitor lactacystin had no effect on the marginal oestradiol-induced ER $\beta$ degradation observed (Peekhaus et al. 2004). However, although the degradation pathways involved in the control of endogenous ER $\beta$ cannot be directly compared with those created by over-expression of the ER $\beta$ expression protein in this cell model, the data suggested that the proteasome pathway must be inhibited before treatment of the cells with oestradiol, a state not investigated in the Peekhaus et al. (2004) study. The results of our study have suggested that ER $\beta$ is also a target for the proteasome in human breast cancer-derived cells. By both western blot and immunocytochemical staining methods, we have confirmed that ER $\alpha$ is targeted for degradation via the proteasome pathway on binding oestradiol, but not tamoxifen, in the MCF-7 cell line (Figs $4 \mathrm{a}$ and $5 \mathrm{~g}$ and i) (Wijayaratne \& McDonnell 2001).

A key finding of this study was that unliganded ER $\alpha$ protein was found to increase in MCF-7 cells with an inhibited proteasome pathway; this was not found for ER $\beta$ (Figs 4a and $c$ and 5f). These findings confirmed that ER $\alpha$ is a target for the proteasome pathway in an unliganded state and, in the absence of an active proteasome and ligand, ER $\alpha$ is ubiquitinated and immobilised in the nuclear matrix (Reid et al. 2003). It is interesting to note that in this instance no increase in ER $\beta$ protein was observed; we suggest that, unlike ER $\alpha$, $\operatorname{ER} \beta$ is not a target for the proteasome in an unliganded state in the MCF-7 cell type. Tamoxifen did not lead to reduced levels of ER $\alpha$ or ER $\beta$ proteins in the MCF-7 cell type, suggesting that tamoxifen binding stabilises both the receptors, in line with the findings of others (Wijayaratne \& McDonnell 2001, Preisler-Mashek et al. 2002, Tschugguel et al. 2003) (Fig. 4a and c). It is of note that tamoxifen, although leading to an increase in ER $\beta$ protein, led to a decrease in ER $\beta$ mRNA, providing evidence for the hypothesis that this compound stabilises the protein and does not increase protein synthesis. Tamoxifen and $E_{2}$ have opposite effects on ER subtype stability in the breast cell line investigated, supporting tamoxifen's role as an anti-oestrogen in breast cancer.

In this study, $\mathrm{E}_{2}$ and tamoxifen have analogous effects on ER degradation in the uterine cell type. We have demonstrated for the first time that tamoxifen induces ligand-mediated degradation of ER $\beta$ protein, an effect requiring an active proteasome (Fig. $4 \mathrm{~d}$ ). In other cell lines, tamoxifen increases ER stability (Lonard \& Smith 2002, Marsaud et al. 2003, Peekhaus et al. 2004). Increasing the ER $\beta: E R \alpha$ ratio by transfection in $\mathrm{T} 47 \mathrm{D}$ cells reduces ER $\alpha$-mediated proliferation (Strom et al. 
(a)
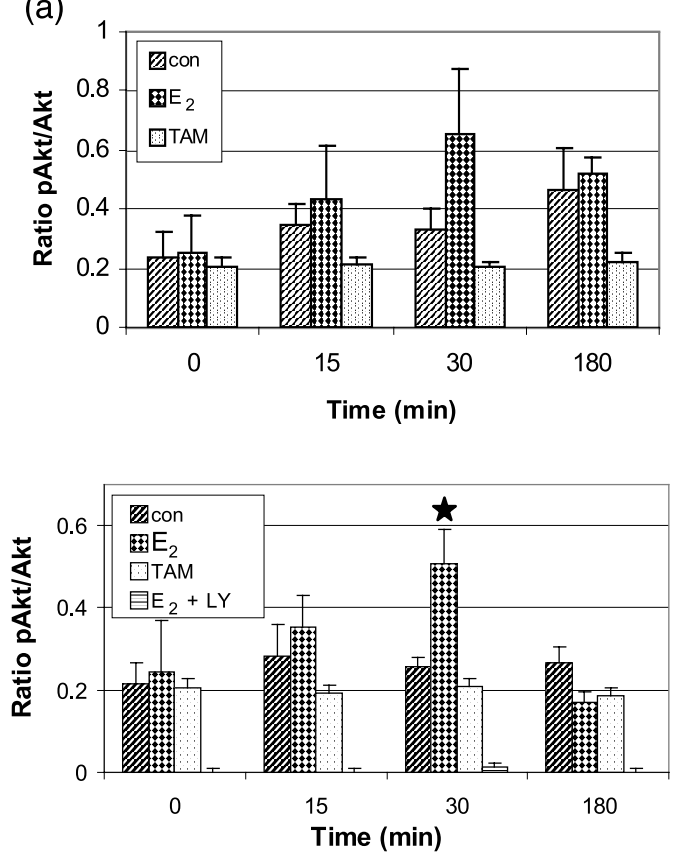

(b)
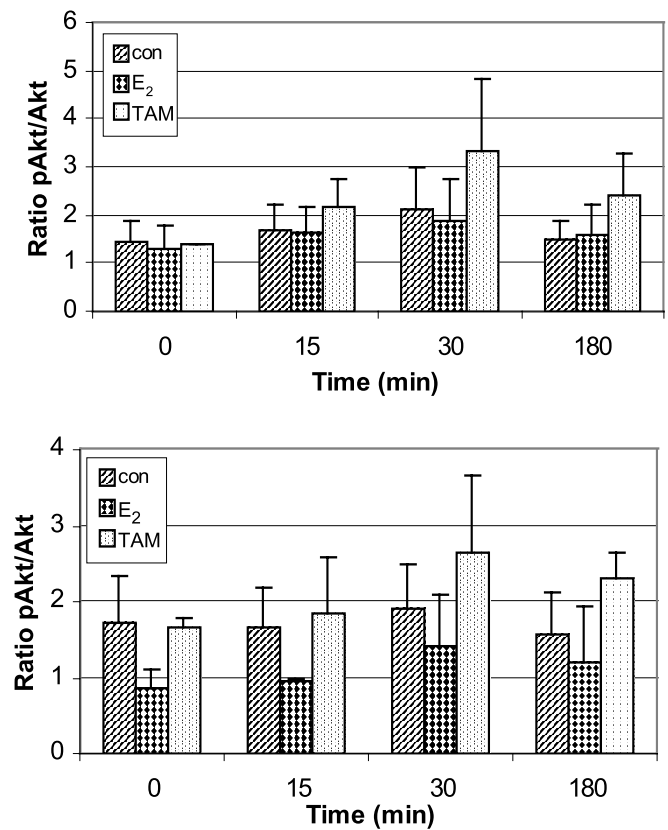

Figure 7 Representative graphs and western blot analysis of Akt and phosphorylated Akt protein levels in (a) MCF-7 and (b) Ishikawa cells. Cell lines were maintained in phenol red-free DMEM/F12 or RPMI containing $10 \%$ DCST-FCS for $72 \mathrm{~h}$, pretreated with $10^{-6} \mathrm{M}$ MG115 or $50 \mu \mathrm{M}$ LY2940002 for $1 \mathrm{~h}$ before dosing with $10^{-8} \mathrm{M} \mathrm{E}_{2}$ or $10^{-6} \mathrm{M}$ TAM. Whole cell lysates were prepared at $0,15,30$ and $180 \mathrm{~min}$. Protein expression is expressed as a ratio of pAkt/Akt normalised to GAPDH expression from mean values \pm S.E. of three experiments. ${ }^{*} P \leq 0.05$ (ANOVA). (a)

(+MG115)
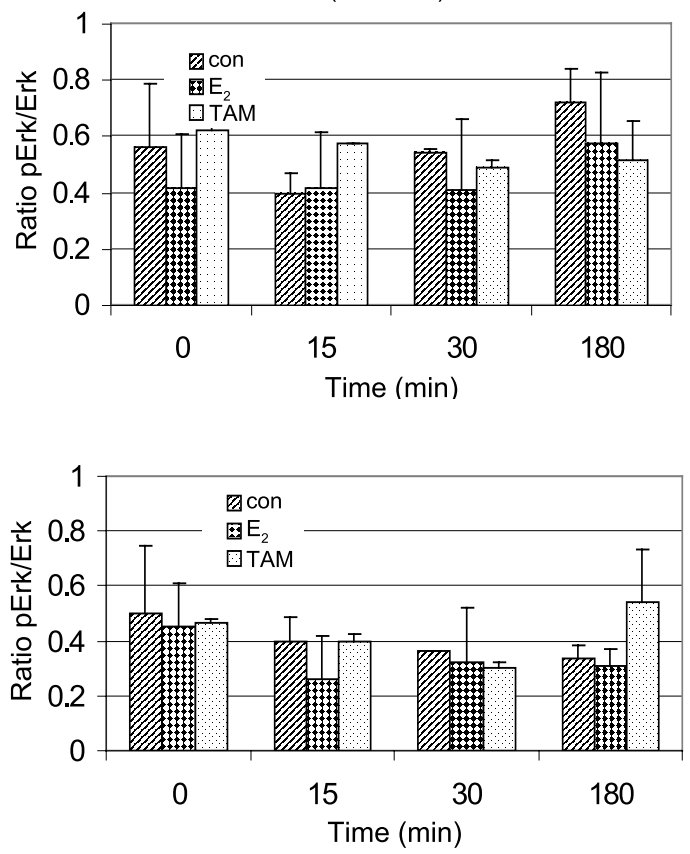

(b)

(+MG115)
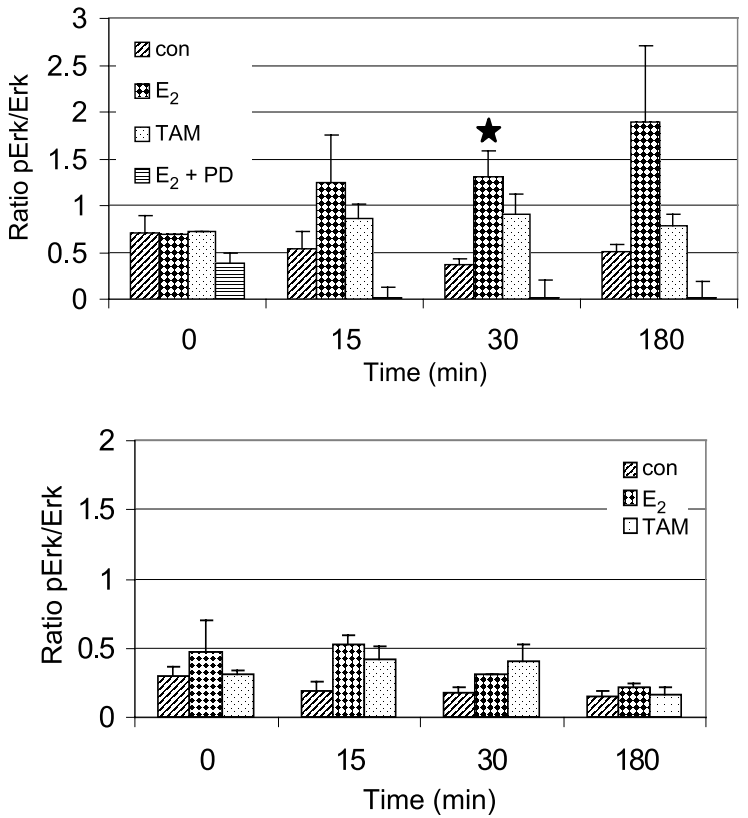

Figure 8 Representative graphs of western blot analysis of Erk and phosphorylated Erk (pERk) protein levels in (a) MCF-7 and (b) Ishikawa cells. Cell lines were maintained in phenol red-free DMEM/F12 or RPMI containing $10 \%$ DCST-FCS for $72 \mathrm{~h}$, pretreated with $10^{-6} \mathrm{M} \mathrm{MG} 115$ for $1 \mathrm{~h}$ before dosing with $10^{-8} \mathrm{M} \mathrm{E}_{2}$ or $10^{-6} \mathrm{M}$ TAM. 30 MM PD98059 (PD) was used to inhibit $E_{2}$-induced Erk phosphorylation in the Ishikawa cell type. Whole cell lysates were prepared at $0,15,30$ and $180 \mathrm{~min}$. Protein expression is expressed as a ratio of pErk/Erk normalised to GAPDH expression from mean values \pm S.E. of three experiments. ${ }^{*} P \leq 0.05$ (ANOVA).

Journal of Molecular Endocrinology (2005) 35, 421-432 
2004); we suggest that tamoxifen's ability to downregulate $\operatorname{ER} \beta$ may play a role in the proliferative effects of the drug in the human uterus (Tomas et al. 1995, Goldstein 2001). $E_{2}$ induces ligand-mediated degradation of $\mathrm{ER} \beta$ thus reducing the $\mathrm{ER} \beta: \mathrm{ER} \alpha$ ratio in this cell type, allowing $\mathrm{ER} \alpha$-mediated proliferation to proceed. Interestingly, Wijayaratne \& McDonnell (2001) demonstrated that tamoxifen could induce degradation of a mutant ER $\beta$ protein unable to bind DNA, suggesting that the DNA-binding capacity of the receptor was necessary for stabilisation of the protein by this ligand. As observed in the MCF-7 cells, unliganded ER $\beta$ proteins are not subject to proteasomal degradation, suggesting that a ligand-induced conformational change is required for ubiquitination to occur (Fig. 4d).

These converse effects of oestradiol and tamoxifen on ER subtype degradation are in line with the hypotheses that the classical model for ER signalling is oversimplified, and various other cell-specific co-activators and co-repressors bind to and influence activation and degradation of the ligand-bound receptors within different target cell types (Nawaz et al. 1999, Lonard et al. 2000, McKenna \& O'Malley 2001, Uchikawa et al. 2003). It is clear that ligand-induced conformational changes, allowing interaction with cell-specific cofactors, are key in target cell response to oestrogen and SERMs. Further characterisation studies are required to determine which proteins are central components in this pathway and their expression levels within the two cell types.

To further evaluate the effect of $\mathrm{E}_{2}$ and tamoxifen on the transcriptional activities of the ERs we investigated the involvement of ER in the activation of pathways leading to phosphorylation of the Akt and Erk proteins in both breast and uterine cell lines. Recent studies have described rapid non-genomic actions of ER stimulated by $\mathrm{E}_{2}$ leading to a substantial increase in pAkt and cell proliferation in MCF-7 (Marquez \& Pietras 2001) and vascular endothelial cells (Pedram et al. 2002). Integration of non-genomic and genomic activation of ER $\alpha$ has been described, involving oestrogen activation of the $\mathrm{PI} 3 \mathrm{~K} / \mathrm{Akt}$ pathway through $\mathrm{ER} \alpha$, terminating in interaction with nuclear ER $\alpha$ altering its expression and activity in MCF-7 cells (Stoica et al. 2003). Following confirmation that in MCF-7 cells $\mathrm{E}_{2}$ treatment rapidly increases pAkt levels, we have shown that tamoxifen does not stimulate phosphorylation of Akt (Fig. 7b). We propose that tamoxifen's inability to activate the PI3K/Akt signalling pathway in MCF-7 cells may contribute to its inhibition of cell proliferation. $\mathrm{E}_{2}$ or tamoxifen did not activate phosphorylation of Akt in Ishikawa cells, suggesting that classical genomic activation of transcription is responsible for the proliferative effects of these compounds in the uterine cell type.

In contrast to Akt, no increase in phosphorylation of Erk1/2 was observed following $\mathrm{E}_{2}$ or tamoxifen treatment of MCF-7 cells (Fig. 8a) confirming previous reports (Lobenhofer \& Marks 2000, Caristi et al. 2001) but conflicting with others (Song et al. 2002). We confirmed that the MAPK/Erk signalling cascade could be activated in our MCF-7 cell model by EGF, a well-documented activator of the MAPK cascade, and therefore suggest that varying experimental conditions including culture media, cell type variation and sensitivity of detection methods could explain this discrepancy. We have demonstrated for the first time $\mathrm{E}_{2}$-induced phosphorylation of Erk1/2 in the Ishikawa cell type only in the absence of an active proteasome pathway (Fig. 8b). We have shown that $\operatorname{ER} \beta$ is rapidly degraded via the proteasome pathway in response to $\mathrm{E}_{2}$, and an excess of ER $\beta$ protein levels within the cell, in the presence of MG115, may lead to increased activation of Erk1/2 phosphorylation in this cell type. Further investigations are required to determine the role of $\mathrm{ER} \beta$ in non-genomic signalling, although evidence from the ERKO mouse model describes oestrogeninduced activation of the MAPK signalling cascade, suggesting a role for ER $\beta$ (Singh et al. 2000).

In conclusion, our data have demonstrated tamoxifen and $\mathrm{E}_{2}$ control of ER subtype stability and that non-genomic activation of transcription pathways is cell specific.

\section{Acknowledgements}

The authors would like to thank Anna Simpson for excellent technical support. The authors declare that there is no conflict of interest that would prejudice the impartiality of this scientific work.

\section{References}

Barchiesi F, Jackson EK, Imthurn B, Fingerle J, Gillespie DG \& Dubey RK 2004 Differential regulation of oestrogen receptor subtypes alpha and beta in human aortic smooth muscle cells by oligonucleotides and estradiol. Fournal of Clinical Endocrinology and Metabolism 89 2373-2381.

Caristi S, Galera JL, Matarese F, Imai M, Caporali S, Cancemi M, Altucci L, Cicatiello L, Teti D, Bresciani F \& Weisz A 2001 Estrogens do not modify MAP kinase-dependent nuclear signaling during stimulation of early $\mathrm{G}(1)$ progression in human breast cancer cells. Cancer Research $616360-6366$.

Cappelletti V, Saturno G, Miodini P, Korner W \& Daidone MG 2003 Selective modulation of ER-beta by estradiol and xenoestrogens in human breast cancer cell lines. Cellular and Molecular Life Science 60 567-576.

Cuzick J, Powles T, Veronesi U, Forbes J, Edwards R, Ashley S \& Boyle P 2003 Overview of the main outcomes in breast-cancer prevention trials. Lancet $361296-300$.

Dowsett M \& Ashworth A 2003 New biology of the oestrogen receptor. Lancet $\mathbf{3 6 2} 260-262$.

Edwards DP 2000 The role of coactivators and corepressors in the biology and mechanism of action of steroid hormone receptors. Journal of Mammary Gland Biology and Neoplasia 5 307-324. 
Fan M, Nakshatri H \& Nephew KP 2004 Inhibiting proteasomal proteolysis sustains estrogen receptor alpha activation. Molecular Endocrinology

Fotiou S, Hatjieleftheriou G, Kyrousis G, Kokka F \& Apostolikas N 2000 Long-term tamoxifen treatment: a possible aetiological factor in the development of uterine carcinosarcoma: two case-reports and review of the literature. Anticancer Research 20 2015-2020.

Goldstein SR 2001 The effects of SERMs on the endometrium. Annals of the New York Academy of Sciences 949 237-242.

Hall LL, Bicknell GR, Primrose L, Pringle JH, Shaw JA \& Furness PN 1998 Reproducibility in the quantification of mRNA levels by RT-PCR-ELISA and RT competitive-PCR-ELISA. Biotechniques 24 652-658.

Jones P, Parrott E \& White INH 1999 Activation of transcription by estrogen receptor alpha and beta is cell type and promoter dependent. Journal of Biological Chemistry 274 32008-32014

Journe F, Body JJ, Leclercq G, Nonclercq D \& Laurent G 2004 Estrogen responsiveness of IBEP-2, a new human cell line derived from breast carcinoma. Breast Cancer Research and Treatment $\mathbf{8 6}$ 39-53.

Kelly MJ \& Levin ER 2001 Rapid actions of plasma membrane estrogen receptors. Trends in Endocrinology and Metabolism 12 $152-156$.

Kisselev AF, Akopian TN, Woo KM \& Goldberg AL 1999 The sizes of peptides generated from protein by mammalian 26 and $20 \mathrm{~S}$ proteasomes. Implications for understanding the degradative mechanism and antigen presentation. Fournal of Biological Chemistry $2743363-3371$.

Klinge CM 2001 Estrogen receptor interaction with estrogen response elements. Nucleic Acids Research 29 2905-2919.

Kloos I, Delaloge S, Pautier P, Di Palma M, Goupil A, Duvillard P, Cailleux PE \& Lhomme C 2002 Tamoxifen-related uterine carcinosarcomas occur under/after prolonged treatment: report of five cases and review of the literature. International foumal of Gynecological Cancer 12 496-500.

Lobenhofer EK \& Marks JR 2000 Estrogen-induced mitogenesis of MCF-7 cells does not require the induction of mitogen-activated protein kinase activity. Foumal of Steroid Biochemistry and Molecular Biology 75 11-20.

Lonard DM \& Smith CL 2002 Molecular perspectives on selective estrogen receptor modulators (SERMs): progress in understanding their tissue-specific agonist and antagonist actions. Steroids $\mathbf{6 7}$ $15-24$.

Lonard DM, Nawaz Z, Smith CL \& O'Malley BW 2000 The 26S proteasome is required for estrogen receptor-alpha and coactivator turnover and for efficient estrogen receptor-alpha transactivation. Molecular Cell 5 939-948.

Lopes UG, Erhardt P, Yao R \& Cooper GM 1997 p53-dependent induction of apoptosis by proteasome inhibitors. Fournal of Biological Chemistry 272 12893-12896.

McDonnell DP, Wijayaratne A, Chang CY \& Norris JD 2002 Elucidation of the molecular mechanism of action of selective estrogen receptor modulators. American Fournal of Cardiology $\mathbf{9 0}$ $35 \mathrm{~F}-43 \mathrm{~F}$.

McKenna NJ \& O'Malley BW 2001 Nuclear receptors, coregulators, ligands, and selective receptor modulators: making sense of the patchwork quilt. Annals of the New York Academy of Sciences 949 3-5.

Marquez DC \& Pietras RJ 2001 Membrane-associated binding sites for estrogen contribute to growth regulation of human breast cancer cells. Oncogene 20 5420-5430.

Marsaud V, Gougelet A, Maillard S \& Renoir J-M 2003 Various phosphorylation pathways, depending on agonist and antagonist binding to endogenous estrogen receptor a, differentially affect ERa extractability, proteasome-mediated stability, and transcriptional activity in human breast cancer cells. Molecular Endocrinology 17 2013-2027.

Nandi D, Woodward E, Ginsburg DB \& Monaco IJ 1997 Intermediates in the formation of mouse $20 \mathrm{~S}$ proteasomes: implications for the assembly of precursor beta subunits. EMBO fournal 16 5363-5375.

Nawaz Z, Lonard DM, Smith CL, Lev-Lehman E, Tsai SY, Tsai MJ \& O'Malley BW 1999 The Angelman syndrome-associated protein, E6-AP, is a coactivator for the nuclear hormone receptor superfamily. Molecular and Cellular Biology 19 1182-1189.

Pakdel F, Le Goff P \& Katzenellenbogen BS 1993 An assessment of the role of domain $\mathrm{F}$ and PEST sequences in estrogen receptor half-life and bioactivity. Fournal of Steroid Biochemistry and Molecular Biology 46 663-672.

Park WC \& Jordan VC 2002 Selective estrogen receptor modulators (SERMS) and their roles in breast cancer prevention. Trends in Molecular Medicine 8 82-88.

Pedram A, Razandi M, Aitkenhead M, Hughes CG \& Levin ER 2002 Integration of the non-genomic and genomic actions of estrogen. Membrane-initiated signaling by steroid to transcription and cell biology. Fournal of Biological Chemistry 277 50768-50775.

Peekhaus NT, Chang T, Hayes EC, Wilkinson HA, Mitra SW, Schaeffer JM \& Rohrer SP 2004 Distinct effects of the antiestrogen Faslodex on the stability of estrogen receptors-alpha and -beta in the breast cancer cell line MCF-7. Fournal of Molecular Endocrinology 32 987-995.

Pole JC, Gold LI, Orton T, Huby R \& Carmichael PL 2005 Gene expression changes induced by estrogen and selective estrogen receptor modulators in primary-cultured human endometrial cells: signals that distinguish the human carcinogen tamoxifen Toxicology 206 91-109.

Power KA \& Thompson LU 2003 Ligand-induced regulation of ERalpha and ERbeta is indicative of human breast cancer cell proliferation. Breast Cancer Research and Treatment 81 209-221.

Preisler-Mashek MT, Solodin N, Stark BL, Tyriver MK \& Alarid ET 2002 Ligand-specific regulation of proteasome-mediated proteolysis of estrogen receptor-alpha. American Fournal of Physiology - Endocrinology and Metabolism 282 E891-E898.

Razandi M, Pedram A, Greene GL \& Levin ER 1999 Cell membrane and nuclear estrogen receptors (ERs) originate fro m a single transcript: studies of ERalpha and ERbeta expressed in Chinese hamster ovary cells. Molecular Endocrinology 13 307-319.

Reid G, Hubner MR, Metivier R, Brand H, Denger S, Manu D, Beaudouin J, Ellenberg J \& Gannon F 2003 Cyclic, proteasomemediated turnover of unliganded and liganded ERalpha on responsive promoters is an integral feature of estrogen signaling. Molecular Cell 11 695-707.

Rutqvist LE, Johansson H, Signomklao T, Johansson U, Fornander T \& Wilking N 1995 Adjuvant tamoxifen therapy for early stage breast cancer and second primary malignancies. Stockholm Breast Cancer Study Group. Fournal of the National Cancer Institute $\mathbf{8 7}$ 645-651.

Singh M, Setalo G Jr, Guan X, Frail DE \& Toran-Allerand CD 2000 Estrogen-induced activation of the mitogen-activated protein kinase cascade in the cerebral cortex of estrogen receptor-alpha knock-out mice. Fournal of Neuroscience 20 1694-1700.

Song RX, McPherson RA, Adam L, Bao Y, Shupnik M, Kumar R \& Santen RJ 2002 Linkage of rapid estrogen action to MAPK activation by ERalpha-Shc association and Shc pathway activation. Molecular Endocrinology 16 116-127.

Stoica GE, Franke TF, Moroni M, Mueller S, Morgan E, Iann MC, Winder AD, Reiter R, Wellstein A, Martin MB \& Stoica A 2003 Effect of estradiol on estrogen receptor-alpha gene expression and activity can be modulated by the ErbB2/PI 3-K/Akt pathway. Oncogene 22 7998-8011.

Strom A, Hartman J, Foster JS, Kietz S, Wimalasena J \& Gustafsson JA 2004 Estrogen receptor beta inhibits 17

beta-estradiol-stimulated proliferation of the breast cancer cell line T47D. PNAS 101 1566-1571

Tomas E, Kauppila A, Blanco G, Apaja-Sarkkinen M \& Laatikainen T 1995 Comparison between the effects of tamoxifen and 
toremifene on the uterus in postmenopausal breast cancer patients. Gynecological Oncology 55 261-266.

Tschugguel W, Dietrich W, Zhegu Z, Stonek F, Kolbus A \& Huber JC 2003 Differential regulation of proteasome-dependent estrogen receptor alpha and beta turnover in cultured human uterine artery endothelial cells. Fournal of Clinical Endocrinology and Metabolism 88 2281-2287.

Uchikawa J, Shiozawa T, Shih HC, Miyamoto T, Feng YZ, Kashima H, Oka K \& Konishi I 2003 Expression of steroid receptor coactivators and corepressors in human endometrial hyperplasia and carcinoma with relevance to steroid receptors and Ki-67 expression. Cancer 98 2207-2213.

Wijayaratne AL \& McDonnell DP 2001 The human estrogen receptor-alpha is a ubiquitinated protein whose stability is affected differentially by agonists, antagonists, and selective estrogen receptor modulators. Fournal of Biological Chemistry $\mathbf{2 7 6}$ 35684-35692.

Received 30 June 2005 Accepted 8 August 2005 